\title{
PERILAKU PENGGUNAAN PORTAL $E$-OFFICE DI BANK XYZ DENGAN PENDEKATAN MODEL UTAUT
}

\author{
Robi Priyadi $^{*}$, Arief Daryanto ${ }^{* *}$, dan Irman Hermadi ${ }^{* * *}$ \\ $\left.{ }^{*}\right)$ PT Bank XYZ (Persero) Tbk. \\ Jl. Jend. Sudirman Kav 44-46, Jakarta Pusat 10210 \\ **) Sekolah Bisnis, Institut Pertanian Bogor \\ Jl. Raya Pajajaran, Bogor 16151 \\ $\left.{ }^{* * *}\right)$ Departemen Ilmu Komputer, Fakultas Matematika dan Ilmu Pengetahuan Alam, Institut Pertanian Bogor \\ Jl. Meranti, Wing 20 Level 5 Kampus IPB Dramaga, Bogor, Jawa Barat 16680
}

\begin{abstract}
Bank XYZ, one of the state-owned banks in Indonesia has been implementing a web-based electronic office system, namely DiO (Digital Office System), since 2014. DiO provides a number of office automate facilities, such as office administration/management, word processing, and communication/mailing system. This research aims to analyze the most affecting factor that underlies the acceptance and usage of DiO by the employees (respondents) using the Unified Theory of Acceptance and Use of Technology (UTAUT) model approach. The study was conducted by using online survey involving employees of Bank XYZ. 380 samples were collected by using the judgment sampling method. Structural Equation Model (SEM) was applied to analyze the data collected from the respondents. The result shows that the employees' use behavior of DiO was significantly influenced by the behavioral intention to use and facility condition. Furthermore, the employees'behavioral intention to use DiO system is significantly influenced by performance expectancy; on the contrary, effort expectancy and social influence have no effect.
\end{abstract}

Keywords: e-office, DiO System, UTAUT model, behavioral intention to use, use behavior, SEM

\begin{abstract}
ABSTRAK
Bank XYZ, salah satu bank milik pemerintah yang telah menerapkan sistem elektronik office, disebut DiO (Digital Office System) sejak tahun 2014. Aplikasi DiO mengakomodir beberapa fasilitas otomasi dalam bentuk pengelolaan administrasi perkantoran, pengolahan kata dan komunikasi/pengiriman surat menyurat. Penelitian ini bertujuan untuk menganalisis faktor-faktor yang memengaruhi perilaku penggunaan DiO oleh karyawan Bank XYZ dengan pendekatan model the Unified Theory of Acceptance and Use of Technology (UTAUT). Penelitian telah dilaksanakan dengan melibatkan karyawan Bank XYZ sebagai responden. Sampel sebanyak 380 dikumpulkan dengan menggunakan metode judgement sampling. Data dianalisis dengan Structural Equation Model(SEM). Hasil penelitian menunjukkan perilaku penggunaan DiO secara aktual (use behavior) dari karyawan Bank XYZ secara signifikan dipengaruhi oleh behavioral intention to use dan fasilitas pendukung. Behavioral intention to use DiO karyawan Bank XYZ hanya terbentuk karena pengaruh harapan kinerja sementara harapan usaha dan pengaruh sosial tidak berpengaruh.
\end{abstract}

Kata kunci: e-office, sistem DiO, model UTAUT, behavioral intention to use, use behavior, SEM

\footnotetext{
${ }^{1}$ Alamat Korespondensi:

Email: shafathar@gmail.com
} 


\section{PENDAHULUAN}

Dinamika lingkungan bisnis menuntut perusahaan melakukan penyesuaian dengan melakukan beberapa perubahan dalam organisasi. Perubahan yang dilakukan akan berdampak langsung terhadap organisasi termasuk anggota organisasi sehingga perlu dikelola dengan baik. Salah satu bentuk pengelolan perubahan dalam organisasi adalah inovasi. Menurut Razavi dan Attarnezhad (2013), inovasi organisasi adalah mekanisme yang diterapkan sebagai adaptasi atas perubahan kondisi persaingan, kemajuan teknologi dan perluasan pasar. Selain itu, inovasi organisasi juga dapat didefinisikan sebagai kemampuan organisasi untuk melakukan renovasi ide dan pengetahuan menjadi produk dan jasa baru atau perbaikan proses secara terus menerus dalam organisasi untuk kepentingan stakeholders. Bank XYZ, salah satu bank milik pemerintah, mengelola perubahan dengan melakukan banyak inovasi dalam rangka menghadapi persaingan usaha perbankan di Indonesia yang semakin ketat. Inovasi dalam bidang human capital, operasional dan teknologi yang diterapkan berhasil menjadikan Bank XYZ menjadi bank pemerintah berkinerja sangat baik (Sutianto, 2015).

Salah satu strategi pengelolaan usaha yang dilakukan Bank XYZ adalah melakukan penetrasi pasar dengan memperluas cakupan wilayah pemasaran melalui penambahan jaringan kerja operasional. Akselerasi pembukaan jaringan kerja operasional di remote area, pedesaan dan perkotaan dilakukan oleh Bank XYZ. Sesuai annual report Bank XYZ(2016), jumlah jaringan kerja operasional Bank XYZ hingga akhir tahun 2015 tercatat telah mencapai 10.612 unit kerja yang tersebar di seluruh wilayah Indonesia. Pengelolaan jaringan kantor operasional yang tersebar dan dalam jumlah yang banyak ini, menurut Bank XYZ perlu memilih strategi yang efektif dan efisien dengan melakukan banyak inovasi.

Salah satu hasil inovasi dalam bidang teknologi dan sistem informasi yang dikembangkan oleh Bank XYZ adalah portal electronic office (e-office) dalam bentuk web based. Menurut Abifarin (1993), e-office adalah sistem otomatis yang dirancang khusus untuk mengelola administrasi perkantoran, pengolah kata dan fasilitas transmisi data, komunikasi/mailing dengan sistem komputasi. Dengan e-office, workflow pengelolaan administrasi perkantoran manual beralih menjadi elektronik. Berinovasi dengan e-office merupakan upaya Bank XYZ melakukan peningkatan efisiensi dan produktivitas di seluruh jaringan kerja operasional. Efisiensi dapat dicapai melalui penghematan biaya overhead karena kegiatan administrasi perkantoran menjadi lebih paperless dan produktivitas dapat ditingkatkan karena informasi menjadi lebih cepat diperoleh, diolah dan disimpan sehingga proses pengambilan keputusan oleh manajemen dapat lebih cepat dilakukan.

Portal e-office di Bank XYZ dikenal dengan nama aplikasi digital office (DiO). DiO dikembangkan dengan cara menempatkan link portal web e-office ke dalam aplikasi Employee Self Service (ESS) sehingga $\mathrm{DiO}$ menjadi bagian dari aplikasi ESS yang dimiliki Bank XYZ. ESS Bank XYZ merupakan aplikasi sistem SDM terintegrasi yang yang sudah ada dan telah diimplementasikan terlebih dahulu sehingga telah dikenal luas oleh seluruh karyawan. O'Brien dan Marakas (2010) menyatakan bahwa ESS adalah aplikasi berbasis web yang memfasilitasi karyawan untuk mengakses data personal dan ketenagakerjaan secara mandiri sehingga karyawan dapat bertransaksi urusan personalia tanpa bertemu langsung dengan unit layanan personalia.

Pengembangan DiO diawali tahun 2012 dan mulai diperkenalkan kepada pengguna tahun 2013 melalui piloting project yang melibatkan beberapa unit kerja di Kantor Pusat Bank XYZ. Setelah melalui pengujian teknis, manajemen Bank XYZ menetapkan secara resmi implementasi aplikasi di Bank XYZ pada tahun 2014. Tahun 2015, versi terakhir dari $\mathrm{DiO}$ (versi V.2.0.3) diperkenalkan kepada seluruh pengguna. Selama tahap pengenalan hingga implementasi, pengguna $\mathrm{DiO}$ mengalami peningkatan. Awal diperkenalkan (akhir 2013), jumlah pengguna DiO tercatat baru mencapai 486 orang. Jumlah pengguna naik menjadi 7.751 orang (akhir 2014) dan naik menjadi menjadi 17.930 orang (akhir 2015).

Walaupun data pada posisi dua tahun terakhir ini memperlihatkan kenaikan jumlah pengguna DiO hingga $31,3 \%$, tetapi jumlah pengguna $\mathrm{DiO}$ pada posisi terakhir (tahun 2015) dapat dikatakan relatif rendah yaitu baru mencapai 13,8\% jika dibandingkan dengan jumlah karyawan aktif yang tercatat sebanyak 129.769 orang berdasarkan publikasi Bank XYZ pada annual report (2016). Fakta ini merupakan fakta penting yang 
perlu dipertimbangkan Bank XYZ untuk melakukan evaluasi pascaimplementasi aplikasi baru dalam rangka optimalisasi penggunaan aplikasi di masa datang. Terlebih lagi, isu kegagalan implementasi suatu sistem aplikasi tidak lagi mengarah kepada isu keteknisan, namun lebih mengarah isu perilaku penggunaan terutama penerimaan pengguna (Wiyono et al. 2008, yang dikutip oleh Tane, 2014). Perilaku penggunaan sistem aplikasi memberikan gambaran mengenai faktor-faktor yang memengaruhi penerimaan pengguna terhadap aplikasi sehingga memberikan kecukupan informasi bagi pengambil keputusan untuk menetapkan strategi optimalisasi yang diambil dalam menerapkan aplikasi baru. Untuk itu, Bank XYZ perlu melakukan evaluasi penerimaan pengguna pascaimplementasi terhadap aplikasi.

Studi mengenai adopsi dan penerimaan pengguna terhadap teknologi dan sistem informasi telah banyak dilaporkan dalam bentuk model penerimaan pengguna. Model penerimaan ini didasari oleh konsep bahwa pembentuk model penerimaan pengguna adalah reaksi penggunaan teknologi secara aktual (use behavior) yang dapat terjadi baik secara langsung tanpa pembentukan behavioral intention to use terlebih dahulu atau harus melalui tahap pembentukan behavioral intention to use oleh pengguna. Atas dasar konsep ini, banyak peneliti terdahulu melakukan pengembangan model penerimaan pengguna (Venkatesh et al. 2003).

Davis (1989) memperkenalkan Technology Acceptance Model (TAM) sebagai salah satu model yang diadopsi untuk menggambarkan penerimaan pengguna. Model ini selanjutnya banyak digunakan dalam beberapa studi lainnya (Park, 2009; Teo, 2010; Renny et al. 2013; Erasmus et al. 2015). Modifikasi TAM dengan model lainnya, yaitu Theory of Planned Behavior (TPB) juga dilaporkan oleh Fusilier dan Durlabhji (2005). Modifikasi TAM lainnya yang disebut Extended Technology Acceptance Model (ETAM) juga dilaporkan oleh Raman (2011) dan Kurz (2012). Menurut Sedana dan Wijaya (2010) dari beberapa model penerimaan teknologiyang diperkenalkan sebelumnya, model the Unified Theory of Acceptance and Use of Technology (model UTAUT) yang diperkenalkan oleh Venkatesh et al. (2003) merupakan model yang lebih banyak digunakan. UTAUT diklaim lebih mampu menjelaskan perilaku penggunaan hingga mencapai lebih dari $70 \%$ (Hamrul et al. 2013).
UTAUT merupakan model penerimaan pengguna yang banyak digunakan peneliti sebelumnya dengan hasil temuan yang beragam (Orji 2010; Sedana dan Wijaya 2010; Oye et al. 2011; Raman 2011; Hsu 2010; Kurz 2012; Oyeet al. 2012; Mandal dan McQueen 2012; Javidniaa et al.2012; Al Qeisi dan Al-Abdallah 2013; Renny et al. 2013; Hamrul et al. 2013; Tane 2014; Al Qeisi dan Al-Abdallah 2014; Raman et al. 2014; Erasmus et al. 2015; Guo 2015). Untuk itu, penelitian ini akan melakukan studi empiris mengenai perilaku penggunaan sistem aplikasi yang baru diimplementasikan dengan pendekatan UTAUT. Objek yang akan dianalisis adalah penggunaan $\mathrm{DiO}$ di Bank XYZ.

Tujuan penelitian ini adalah menganalisis konstruk pembentuk model UTAUT yang berpengaruh terhadap pembentukan behavioral intention to use $\mathrm{DiO}$ dan menganalisis konstruk pembentuk model UTAUT yang berpengaruh terhadap pembentukan perilaku penggunaan aktual (use behavior) DiO. Hasil penelitian akan digunakan sebagai rekomendasi kepada Bank XYZ untuk mengoptimalkan penggunaan $\mathrm{DiO}$ terutama kepada kelompok karyawan yang belum menggunakan DiO berdasarkan perilaku penggunaan dari kelompok karyawan yang telah menggunakan DiO.

\section{METODE PENELITIAN}

Penelitian ini telah dilaksanakan selama empat bulan, dimulai pada bulan Maret sampai dengan bulan Juni 2016, berlokasi di Kantor Pusat Bank XYZ. Penelitian dilakukan secara deskriptif kuantitatif dengan metode cross sectionalsurvey menggunakan kuesioner terstruktur yang dikembangkan mengacu pada struktur model penelitian.

Secara struktural, model penelitian (pada Gambar 1) dibentuk dari empat konstruk utama yang berperan sebagai prediktor behavioral intention to use dan use behavior, yaitu harapan kinerja, harapan usaha, pengaruh sosial dan fasilitas pendukung. Konstruk lain dari model orisinil UTAUT yaitu jenis kelamin, usia, pengalaman dan voluntariness of use yang diposisikan sebagai variabel moderasi dari konstruk pembentuk utama tidak dianalisis dalam penelitian ini. 


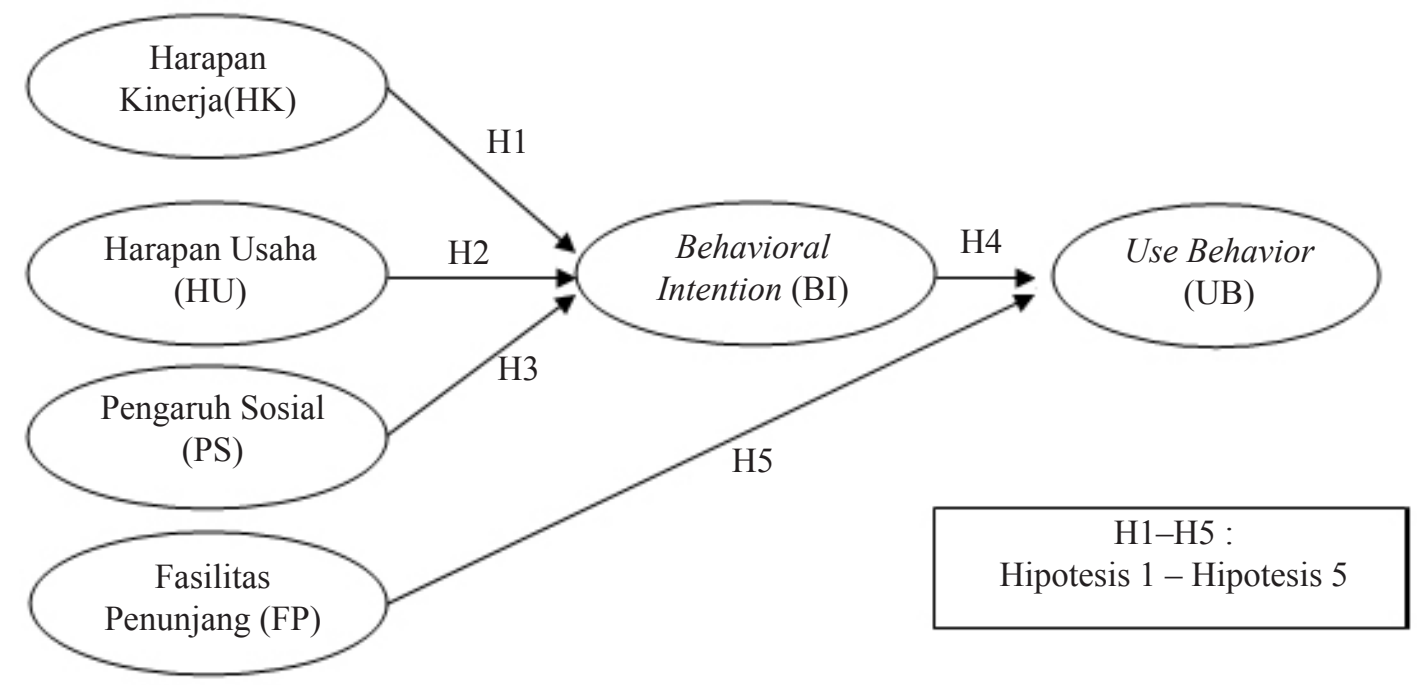

Gambar 1. Model penelitian

Untuk itu, dengan pendekatan model UTAUT (Venkatesh et al. 2003 yang dimodifikasi oleh Sedana dan Wijaya, 2010), kuesioner dirancang dalam dua bagian, yaitu pertanyaan mengenai data umum dan demografi responden serta pernyataan mengenai indikator-indikator yang akan dianalisis. Sikap atau persepsi responden atas pernyataan yang diajukan dalam kuesioner dinyatakan dengan tujuh skala Likert tentang setuju dan tidak setuju.

Variabel operasional dalam penelitian ini adalah sebagai berikut 1) Harapan kinerja (HK) adalah keyakinan menggunakan DiO akan membantu pencapaian keuntungan kinerja, diukur dengan empat indikator: akan menunjang bidang pekerjaan (X1), mempercepat pekerjaan (X2), meningkatkan produktivitas (X3) dan meningkatkan peluang memperoleh nilai kinerja lebih baik (X4). 2) Harapan usaha (HU) adalah kemudahan yang dirasakan karena penggunaan DiO, diukur dengan empat indikator: paham menggunakan (X5), terampil mengoperasikan (X6), mudah digunakan (X7) dan mudah untuk mempelajari pengoperasian (X8). 3) Pengaruh sosial (PS) adalah anggapan orang-orang penting di sekitarnya akan memengaruhi keinginan menggunakan $\mathrm{DiO}$, diukur dengan empat indikator:pihak lain yang memengaruhi perilaku mewajibkanpenggunaan (X9), pihak lain menentukan karir mengharuskan penggunaan (X10), pihak lain sebagai atasan langsung membantu dan mendorong penggunaan (X11) dan secara umum perusahaan mendukung penggunaan (X12); Fasilitas pendukung (FP) adalah kepercayaan bahwa infrastruktur dan fasilitas teknis mendukung penggunaan $\mathrm{DiO}$, diukur dengan empat indikator: tersedia sumberdaya untuk pengoperasian $\mathrm{DiO}$ (X13), kecukupan pengetahuan yang diperlukan untuk pengoperasian DiO (X14), DiO tidak kompatibel dengan sistem atau perangkat lain (X15) dan tersedia tenaga khusus yang membantu menghadapi kesulitan pengoperasiona DiO (X16). 4) Behavioral intention to use (BI) adalah ukuran kekuatan niat berperiku karyawan untuk menggunakan DiO, diukur indikator yaitu karyawan berniat menggunakan DiO mulai bulan depan (Y1). 5) Use behavior (UB) adalah reaksi untuk menggunakan DiO secara aktual, diukur dengan satu indikator yaitu karyawan telah menggunakan DiO selama bekerja di Bank XYZ(Y2).

Hipotesis yang diajukan dalam penelitian ini adalah sebagai berikut:

1. H1: Harapan kinerja dari karyawan Bank XYZ berpengaruh terhadap behavioral intention to use DiO.

2. H2: Harapan akan usaha dari karyawan Bank XYZ berpengaruh terhadap behavioral intention to use DiO.

3. H3: Pengaruh sosial dari karyawan Bank XYZ berpengaruh terhadap behavioral intention to use DiO.

4. H4: Behavioral intention to use darikaryawan Bank $\mathrm{XYZ}$ berpengaruh terhadap perilaku penggunaan secara aktual (use behavior) DiO.

5. H5: Fasilitas pendukung berpengaruh terhadap perilaku penggunaan secara aktual (use behavior) DiO. 
Penyebaran kuesioner dilakukan secara online dengan bantuan e-mail dan Google form kepada karyawan Bank XYZ di seluruh Indonesia meliputi Kantor Cabang Pembantu, Kantor Cabang, Kantor Wilayah, Kantor Inspeksi dan Kantor Pusat. Sampel diambil dengan metode judgement sampling yang dilakukan dengan kriteria yaitu "karyawan Bank XYZ yang masih menggunakan DiO”.

Ukuran sampel ditetapkan dengan pendekatan analisis Structural Equation Model (SEM) sesuai konsep rule of thumb (Bentler dan Chou 1987, dikutip oleh Wijanto, 2015). Dengan pendekatan ini, saat melakukan estimasi Weight least square, satu variabel teramati memerlukan 5 - 10 sampel. Dengan demikian, ukuran sampel ditetapkan minimal sebanyak 180 sampel karena penelitian menggunakan sebanyak 18 variabel teramati. Untuk memenuhi syarat minimal ukuran sampel, jumlah kuesioner yang akan disebarkan, ditetapkan sebanyak 400 set. Dari 400 set kuesioner yang disebarkan, akan dipilih sampel yang memenuhi kriteria yang telah ditetapkan dalam profil penggunaan aplikasi yaitu "karyawan Bank XYZ yang masih menggunakan DiO". Kuesioner yang tidak diisi lengkap atau tidak layak maka tidak akan dipilih sebagai sampel penelitian.

Data dianalisis dengan SEM menggunakan software LISREL (Linear Structural Relation) agar keterkaitan hubungan linear antara variabel-variabel laten secara simultan dapat dideskripsikan. Pengujian yang dilakukan dalam penelitian ini adalah pengujian validitas dan reliabilitas variabel, pengujian hipotesis dan pengujian kecocokan model. Model dikatakan baik dan dapat diterima apabila memenuhi kriteria keabsahan (cut-off) dari Goodness of fit (GOF) keluaran SEM (Wijanto, 2015).

\section{HASIL}

\section{Profil Responden}

Dari 400 set yang disebarkan, sebanyak 380 orang responden mengisi dan mengembalikan kuesioner. Tabel 1 menyajikan profil penggunaan DiO berdasarkan kuesioner yang dikembalikan. Dari 380 set kuesioner yang dikembalikan, sebanyak 315 orang responden dinyatakan memenuhi kriteria judgement sampling yang telah ditetapkan sehingga dipertimbangkan sebagai sampel dalam penelitian ini.

Responden didominasi oleh demografi sebagai berikut: berjenis kelamin laki-laki $(70,16 \%)$; lokasi kantor berada di Pulau Jawa $(61,27 \%)$; berusia $>28-56$ tahun (52,38\%); memiliki level jabatan officer $(58,73 \%)$; berpendidikan terakhir Sarjana (78,73\%); dan memiliki masa kerja antara 0-3 tahun (40,32\%). Tabel 2 menyajikan keseluruhan demografi dari responden yang melakukan pengisian kuesioner.

Tabel 1. Profil penggunaan aplikasi $\mathrm{DiO} *$ )

\begin{tabular}{lcc}
\hline \multicolumn{1}{c}{ Pernyataan profil penggunaan } & Jumlah responden (orang) & $\%$ tase (\%) \\
\hline Saya sudah mengetahui bahwa sudah ada kewajiban menggunakan DiO & 300 & 78.95 \\
Saya belum mengetahui bahwa sudah ada kewajiban menggunakan DiO & 80 & 21.05 \\
Total responden & 380 & 100 \\
Saya sudah pernah mengakses atau melakukan login ke DiO & 315 & 82.89 \\
Saya belum pernah mengakses atau melakukan login ke DiO & 65 & 17.11 \\
Total responden & 380 & 100 \\
Saya sudah pernah mencoba menggunakan DiO & 315 & 82.89 \\
Saya belum pernah mencoba menggunakan DiO & 65 & 17.11 \\
Total responden & 380 & 100 \\
Saya masih menggunakan DiO & 315 & 82.89 \\
Saya tidak lagi menggunakan DiO & 65 & 17.11 \\
Total responden & 380 & 100 \\
\hline
\end{tabular}


Tabel 2. Demografi responden dalam penelitian

\begin{tabular}{|c|c|c|c|}
\hline Demografi & Parameter & Frekuensi & $\%$ tase $(\%)$ \\
\hline \multirow[t]{7}{*}{ Level jabatan } & Executive Vice President & 2 & 0,63 \\
\hline & Vice President & 5 & 1,59 \\
\hline & Senior Manager & 47 & 14,92 \\
\hline & Manager & 24 & 7,62 \\
\hline & Assistant Manager & 4 & 1,27 \\
\hline & Officer & 185 & 58,73 \\
\hline & Assistant & 48 & 15,24 \\
\hline \multirow[t]{2}{*}{ Lokasi kantor } & P. Jawa & 193 & 61,27 \\
\hline & Luar P. Jawa & 122 & 38,73 \\
\hline \multirow[t]{2}{*}{ Jenis kelamin } & Wanita & 94 & 29,84 \\
\hline & Pria & 221 & 70,16 \\
\hline \multirow[t]{2}{*}{ Golongan usia } & 14-28 tahun & 150 & 47,62 \\
\hline & $>28-56$ tahun & 165 & 52,38 \\
\hline \multirow[t]{6}{*}{ Latar belakang pendidikan } & Pascasarjana & 51 & 16,19 \\
\hline & Sarjana & 248 & 78,73 \\
\hline & Diploma/sederajat & 15 & 4,76 \\
\hline & SMA/sederajat & 1 & 0,32 \\
\hline & SMP/sederajat & 0 & 0,00 \\
\hline & $\mathrm{SD} /$ sederajat & 0 & 0,00 \\
\hline \multirow[t]{6}{*}{ Masa kerja } & $>15$ tahun & 59 & 18,73 \\
\hline & $>12-15$ tahun & 24 & 7,62 \\
\hline & $>9-12$ tahun & 25 & 7,94 \\
\hline & $>6-9$ tahun & 20 & 6,35 \\
\hline & $>3-6$ tahun & 60 & 19,05 \\
\hline & $0-3$ tahun & 127 & 40,32 \\
\hline
\end{tabular}

\section{Hasil Uji Konstruk}

Hasil keluaran SEM menunjukkan bahwa secara umum variabel teramati memenuhi validitas dan realiabilitas sehingga dapat dipergunakan sebagai instrumen analisis lebih lanjut. Tabel 3 menyajikan hasil pengujian validitas dan reliabilitas variabelvariabel penelitian. Model struktural yang dihasilkan dari pengujian menggunakan SEM menunjukkan bahwa model memiliki kecocokan (good fit) terhadap data yang dikumpulkan (Gambar 2).

Perbandingan antara nilai chi-square $(\chi 2)=85.21$ dengan derajat bebas $(\mathrm{dF})=67\left(\chi^{2} / \mathrm{dF}\right)$ menghasilkan rasio yang memenuhi salah satu persyaratan kecocokan model yaitu rasio $(\chi 2 / \mathrm{dF})<3.0$ karena berdasarkan perhitungan nilai hasil pengujian didapat rasio $(\chi 2 / \mathrm{dF})=$ 1.27. Pengujian kecocokan model dilakukan dengan pendekatan kriteria kecocokan SEM menggunakan kriteria cut-off dari statistik GOF. Hasil pengujian model dikatakan memadai atau memiliki kecocokan karena memenuhi nilai kriteria cut-off yang sesuai (Tabel 5). Dengan demikian, keseluruhan model penelitian yang dibangun dapat menjelaskan informasi secara empiris sesuai data yang dikumpulkan dari responden. Hal ini menunjukkan bahwa model penelitian telah dapat digunakan dalam melakukan penilaian atau mengukur variabel teramati yang digunakan. 
Tabel 3. Hasil pengujian validitas dan reliabilitas variabel laten

\begin{tabular}{|c|c|c|c|c|c|c|c|}
\hline \multicolumn{2}{|c|}{ Variabel laten } & $\begin{array}{l}\text { Standarized } \\
\text { Loading factor } \\
\text { (SLF) }\end{array}$ & $\mathrm{t}_{\text {hitung }}$ & Validitas*) & $\begin{array}{l}\text { Construct } \\
\text { Reliability } \\
\text { (CR) }\end{array}$ & $\begin{array}{l}\text { Varians } \\
\text { Extracted } \\
\text { (VE) }\end{array}$ & Reliabilitas $^{* *}$ \\
\hline \multicolumn{8}{|c|}{ Variabel Laten Eksogen } \\
\hline \multirow{2}{*}{$\begin{array}{l}\text { Harapan } \\
\text { kinerja }\end{array}$} & $\mathrm{X} 1$ & 0,86 & 18,14 & Valid & \multirow[t]{4}{*}{0.87} & \multirow[t]{4}{*}{0.64} & Reliabel \\
\hline & $\mathrm{X} 2$ & 0,88 & 19,12 & Valid & & & Reliabel \\
\hline \multirow{5}{*}{ Harapan usaha } & $\mathrm{X} 3$ & 0,90 & 19,47 & Valid & & & Reliabel \\
\hline & $\mathrm{X} 4$ & 0,49 & 9,01 & Valid & & & Reliabel \\
\hline & $\mathrm{X} 5$ & 0,83 & 17,55 & Valid & \multirow[t]{4}{*}{0.91} & \multirow[t]{4}{*}{0.72} & Reliabel \\
\hline & $\mathrm{X} 6$ & 0,86 & 18,80 & Valid & & & Reliabel \\
\hline & $\mathrm{X} 7$ & 0,81 & 16,73 & Valid & & & Reliabel \\
\hline \multirow{3}{*}{ Pengaruh sosial } & $\mathrm{X} 8$ & 0,90 & 20,08 & Valid & & & Reliabel \\
\hline & $\mathrm{X} 9$ & 0,56 & 8,57 & Valid & \multirow[t]{4}{*}{0.86} & \multirow[t]{4}{*}{0.64} & Reliabel \\
\hline & $\mathrm{X} 10$ & 0,66 & 11,60 & Valid & & & Reliabel \\
\hline \multirow{6}{*}{$\begin{array}{l}\text { Fasilitas } \\
\text { pendukung }\end{array}$} & $\mathrm{X} 11$ & 0,87 & 15,17 & Valid & & & Reliabel \\
\hline & $\mathrm{X} 12$ & 1,02 & 13,01 & Valid & & & Reliabel \\
\hline & $\mathrm{X} 13$ & 0,84 & 17,65 & Valid & \multirow[t]{2}{*}{0.83} & \multirow[t]{2}{*}{0.71} & Reliabel \\
\hline & $\mathrm{X} 14$ & 0,84 & 17,70 & Valid & & & Reliabel \\
\hline & $\mathrm{X} 15$ & $-0,40$ & $-3,62$ & Tidak Valid & - & - & Tidak Reliabel \\
\hline & $\mathrm{X} 16$ & 0,19 & 1,87 & Tidak Valid & - & - & Tidak Reliabel \\
\hline \multicolumn{8}{|c|}{ Variabel Laten Endogen } \\
\hline $\begin{array}{l}\text { Behavioral } \\
\text { Intention }\end{array}$ & Y1 & 0,81 & 0,00 & Tidak Valid & 0.65 & 0.66 & Reliabel \\
\hline Use Behavior & $\mathrm{Y} 2$ & 1,00 & 0,00 & Tidak Valid & 1.00 & 1.00 & Reliabel \\
\hline
\end{tabular}

${ }^{*} \mathrm{SLF} \geq 0,50$ dan $\left|\mathrm{t}_{\text {hitung }}\right|>1,96$ dan ${ }^{* *} \mathrm{CR} \geq 0,70$ dan $\mathrm{VE} \geq 0,50 \rightarrow$ variabel dikatakan baik

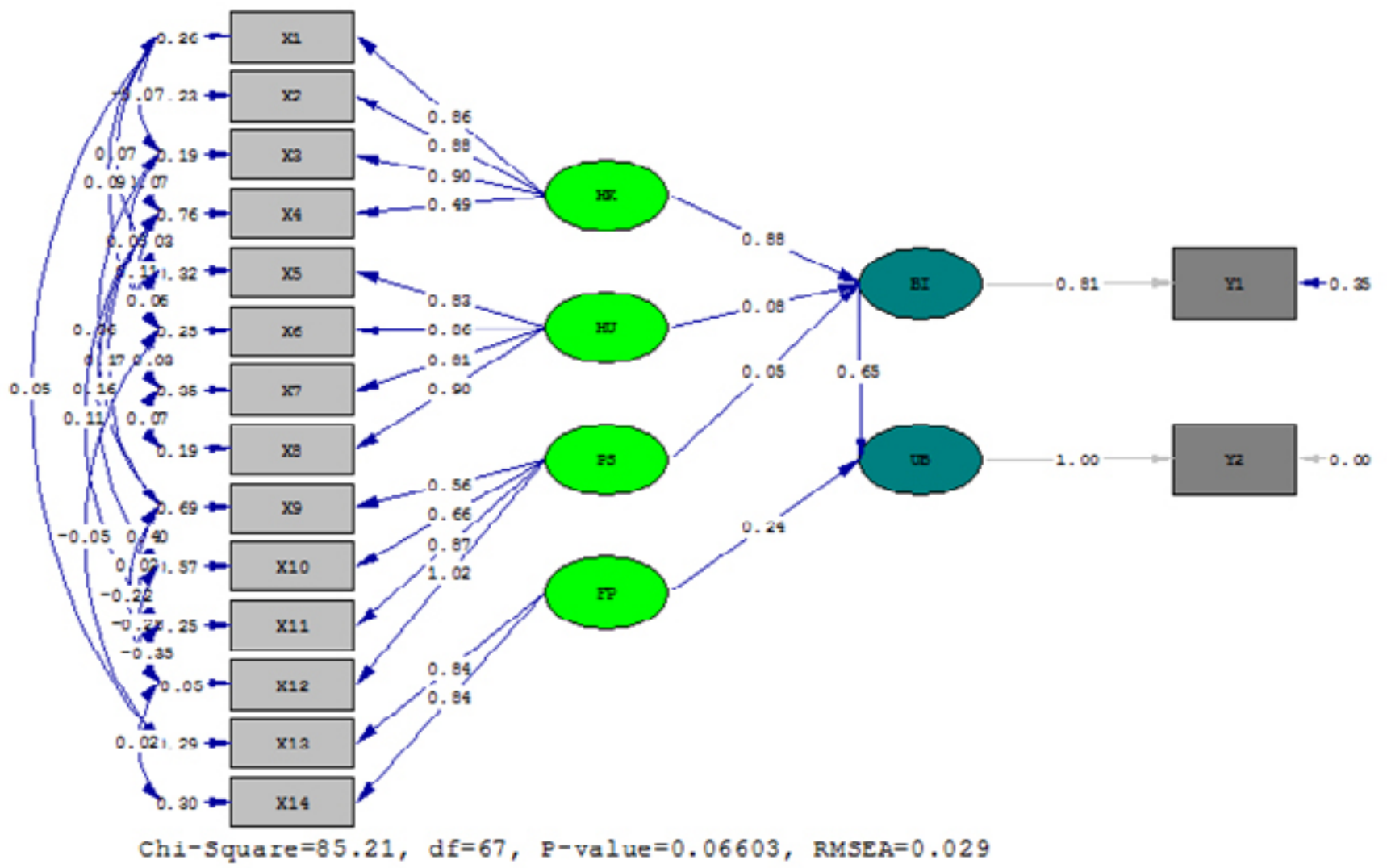

Gambar 2. Struktur model penelitian dengan standarized loading factor 
Tabel 5. Statistik GOF keseluruhan model penelitian

\begin{tabular}{lcc}
\hline & GOF $*$ ) & \multicolumn{2}{c}{ Hasil Pengujian } \\
\cline { 2 - 3 } & \multicolumn{1}{c}{ Nilai } & Simpulan**) \\
\hline P-value & 0,066 & Good fit \\
NCP (Non-centrality Parameter) & 18,21 & Good fit \\
RMSEA (Root Mean Square Error of Approximation) & 0,029 & Good fit \\
GFI (Goodness of fit Index) & 0,970 & Good fit \\
AGFI (Adjusted Goodness of fit Index) & 0,930 & Good fit \\
NNFI (Non-Normed Fit Index) & 0,990 & Good fit \\
NFI (Normed Fit Index) & 0,980 & Good fit \\
RFI (Relative Fit Index) & 0,960 & Good fit \\
IFI (Incremental Fit Index) & 0,990 & Good fit \\
CFI (Comparative Fit Index) & 0,990 & Good fit \\
\hline
\end{tabular}

*) Kriteria cut-off: P-value $>0,05$ (Good Fit); NCP = nilai yang kecil (Good Fit);RMSEA $<0,08$ (Good Fit); 0,08 < RSMEA $<0,10$ (Marginal Fit); RSMEA > 0,10 (Poor Fit); GFI >0,90 (Good Fit); 0,80< GFI <0,90 (Marginal Fit); AGFI $>0,90$ (Good Fit); 0,80< AGFI < 0,90 (Marginal Fit); NNFI > 0,90 (Good Fit); 0,80< NNFI <0,90 (Marginal Fit); NFI $>0,90$ (Good Fit); 0,80< NFI < 0,90 (Marginal Fit); RFI >0,90 (Good Fit); 0,80< RFI <0,90 (Marginal Fit); IFI $>0,90$ (Good Fit); 0,80 < IFI < 0,90 (Marginal Fit); CFI > 0,90 (Good Fit); 0,80 < CFI <0,90 (Marginal Fit).

**) Good fit $=$ memiliki kecocokan model

Pengujian hipotesis dilakukan dengan mengevaluasi path coefficient dan nilai thitung untuk jalur lintasan (path) dari variabel laten sesuai model yang telah ditetapkan. Hasil pengujian hipotesis menunjukkan bahwa bahwa Hipotesis H1, H4 dan H5 dapat diterima sedangkan $\mathrm{H} 2$ dan $\mathrm{H} 3$ ditolak (Tabel 6).

Dengan demikian, variabel laten endogen behavioral intention to use (BI) hanya dipengaruhi oleh variabel laten eksogen harapan kinerja (HK) dan tidak dipengaruhi oleh variabel laten eksogen harapan usaha (HU) dan pengaruh sosial (PS). Variabel laten endogen use behavior (UB) dipengaruhi oleh variabel laten endogen behavioral intention to use (BI) dan variabel laten eksogen fasilitas pendukung (FP).

\section{Konstruk Pembentuk Model UTAUT Terhadap Pembentukan Behavioral Intention to Use DiO}

Temuan bahwa harapan kinerja memengaruhi behavioral intention to use mendukung hasil penelitian sebelumnya (Venkatesh et al. 2003; Sedana dan Wijaya 2010; Nasir 2013; Tane 2014). Temuan bahwa harapan usaha tidak berpengaruh terhadap behavioral intention to use dalam penelitian ini memberikan hasil berbeda dengan hasil yang dilaporkan oleh Venkatesh et al. 2003; Nasir 2013; Tane 2014). Namun, temuan ini memberikan rekomendasi yang sama dengan hasil yang dilaporkan oleh Sedana dan Wijaya (2010) yang menyatakan bahwa harapan usaha tidak memengaruhi behavioral intention to use.
Temuan lain bahwa pengaruh sosial tidak berpengaruh terhadap behavioral intention to use juga memberikan hasil yang berbeda dengan hasil penelitian yang dilaporkan oleh Venkatesh et al. (2003); Sedana dan Wijaya (2010); Nasir (2013); Tane (2014). Selain itu, temuan bahwa lingkungan sosial tidak memengaruhi pembentukan behavioral intention to use maka orang lain di lingkungan kerja responden, yaitu teman, atasan langsung dan perusahaan dikatakan tidak memengaruhi pembentukan niat berperilaku. Dalam perkataan lain, behavioral intention to use terbentuk karena dari dalam diri karyawan bukan karena pengaruhi orang lain di luar diri karyawan.

\section{Konstruk Pembentuk Model UTAUT Terhadap Pembentukan Use Behavior DiO}

Temuan bahwa use behavior dipengaruhi secara signifikan oleh behavioral intention to use dan fasilitas pendukung mendukung hasil penelitian sebelumnya yang telah dilaporkan oleh Venkatesh et al. (2003); Sedana dan Wijaya (2010). Responden menganggap bahwa perilaku mereka menggunakan DiO secara aktual secara signifikan dibentuk atas dasar behavioral intention to use yang kuat terutama yang dibentuk oleh konstruk yang berasal dari keinginan mendapatkan keuntungan kinerja. Selain itu, fasilitas pendukung teknologi dan sistem informasi di Bank XYZ sangat mendukung pembentukan use behavior DiO. 
Tabel 6. Pengujian hipotesis dengan evaluasi path coefficient dan thitung

\begin{tabular}{ccccc}
\hline Hipotesis & Path $^{*}$ ) & Path coefficient & $\mathrm{t}_{\text {Hitung }}$ & Simpulan **) \\
\hline $\mathrm{H} 1$ & $\mathrm{HK} \rightarrow \mathrm{BI}$ & 0,88 & 10,58 & Signifikan \\
$\mathrm{H} 2$ & $\mathrm{HU} \rightarrow \mathrm{BI}$ & 0,08 & 1,12 & Tidak signifikan \\
$\mathrm{H} 3$ & $\mathrm{PS} \rightarrow \mathrm{BI}$ & 0,05 & 1,08 & Tidak signifikan \\
$\mathrm{H} 4$ & $\mathrm{BI} \rightarrow \mathrm{UB}$ & 0,65 & 7,46 & Signifikan \\
$\mathrm{H} 5$ & $\mathrm{FP} \rightarrow \mathrm{UB}$ & 0,24 & 3,00 & Signifikan \\
\hline
\end{tabular}

*) $\mathrm{HK}=$ harapan kinerja, $\mathrm{HU}=$ harapan usaha, $\mathrm{PS}=$ pengaruh sosial, $\mathrm{BI}=$ behavioral intention to use, $\mathrm{FP}=$ fasilitas pendukung, $\mathrm{UB}=$ use behavior.

**) $\left|t_{\text {hitung }}\right|>1,96$ signifikan

\section{Implikasi Manajerial}

Bank XYZ dapat memanfaatkan temuan ini untuk meningkatkan jumlah pengguna DiO seiring dengan target pengembangan dan implementasi yang ditetapkan oleh Bank XYZ. Untuk tercapainya tujuan ini, hal yang dapat dipertimbangkan oleh manajemen bank XYZ adalah memilih strategi didasarkan atas penciptaan urgensi penggunaan $\mathrm{DiO}$.

Penciptaan urgensi penggunaan $\mathrm{DiO}$ yang telah dilakukan oleh Bank XYZ saat ini belum mengarah pada faktor dasar pendorong pembentukan niat karyawan untuk menggunakan aplikasi. Mengacu pada hasil penelitian ini, sosialisasi atau campaign yang seharusnya dapat diterapkan oleh bank XYZ adalah sosialisasi atau campaign yang fokusnya mengarah pada harapan kinerja karyawan. Bank XYZ perlu mengembangkan model sosialisasi atau campaign yang memberikan dorongan kepada karyawan bahwa menggunakan DiO dapat memberikan manfaat yang berdampak langsung terhadap kinerja individu yaitu mempermudah penyelesaian pekerjaan, meningkatkan produktivitas dan memberikan peluang meningkatkan kinerja.

Alternatif strategi penciptaan urgensi penggunaan $\mathrm{DiO}$ yang dapat dipertimbangkan oleh manajemen Bank XYZ lainnya yaitu dengan menetapkan penggunaan DiO sebagai salah satu indikator kinerja kunci yang harus dicapai oleh karyawan pada saat penilaian kinerja dan memberlakukan sistem reward kepada karyawan yang menggunakan $\mathrm{DiO}$ dengan pemberian insentif pada angka kinerja individu dan sebaliknya memberikan punishment yang tegas kepada karyawan yang tidak menggunakan $\mathrm{DiO}$ dengan memberikan penalti pada angka kinerja individu.

\section{KESIMPULAN DAN SARAN}

\section{Kesimpulan}

Pentingnya hasil penelitian ini bagi Bank XYZ, yaitu sebagai rekomendasi untuk mengoptimalkan penggunaan berdasarkan perilaku penggunaan dari kelompok karyawan yang telah menggunakan $\mathrm{DiO}$ mendasari pelaksanaan penelitian ini sehingga dapat dianalisisfaktor pembentuk perilaku penggunaan aplikasi DiO yang paling signifikan dengan pendekatan model UTAUT. Adapun simpulan yang diambil dari penelitian ini adalah pembentukan behavioral intention to use DiO dari karyawan Bank XYZ hanya dipengaruhi oleh harapan kinerja sedangkan harapan usaha dan pengaruh sosial tidak berpengaruh. Selanjutnya, perilaku penggunaan DiO secara aktual (use behavior) dari karyawan Bank XYZ dipengaruhi oleh behavioral intention to use dan fasilitas pendukung

\section{Saran}

Dari hasil penelitian ini, saran dari penelitian ini adalah melakukan penelitian lanjutan dengan mempertimbangkan faktor teknis antara lain lokasi kantor sebagai variabel laten lain terutama pada interaksi konstruk fasilitas pendukung terhadap pembentukan use behavior DiO. Hal ini perlu dilakukan untuk mendapatkan informasi yang lebih komprehensif mengenai pembentuk use behavior $\mathrm{DiO}$ mengingat lokasi kantor Bank XYZ yang terbesar dan tersebar di seluruh Indonesia.

\section{DAFTAR PUSTAKA}

Abifarin FP. 1993. The prospects for an electronic office in Nigerian libraries. Library Management Copyright MCB University Press 14 (4): 25-30. 
Al Qeisi KI dan Al-Abdallah G. 2013. Internet banking adoption in Jordan: a behavioral approach. International Journal of Marketing Studies 5(6): 84-108.

Al Qeisi KI dan Al-Abdallah G. 2014. Website design and usage behaviour: an application of the UTAUT model for internet banking in UK. International Journal of Marketing Studies 6(1): 75-89.

Davis FD. 1989. Perceived usefulness, perceived ease of use, and user acceptance of information technology. MIS Quarterly 13(3):318-339. doi:10.2307/ 249008.

[Divisi SKP XYZ] Divisi Sekretariat Perusahaan PT Bank XYZ (Persero) Tbk. 2016. Annual Report XYZ 2015. Jakarta: Divisi SKP XYZ.

Erasmus E, Rothmann S, VanEeden C. 2015. A structural model of technology acceptance. $S A$ Journal of Industrial Psychology 41(1):12-22.

Fusilier M, Durlabhji S. 2005. An exploration of student internet use in India: The technology acceptance model and the theory of planned behaviour. Campus - Wide Information Systems 22(4): 233-246.

Guo Y. 2015. ModeRating effects of gender in the acceptance of mobile SNS based on UTAUT model. International Journal of Smart Home 9(1): 203-216.

Hamrul H, Soedijono B, Amborowati A. 2013. Analisis perbandingan metode TAM dan UTAUT dalam mengukur kesuksesan penerapan sistem informasi akademik (studi kasus penerapan sistem informasi STMIK dipanegara Makassar). Di dalam: Seminar Nasional Informatika, Yogyakarta, 18 Mei 2013. UPN Yogyakarta. Hlm. A.140 - A.146.

Hsu HH. 2012. The acceptance of moodle: an empirical study based on UTAUT. Scientific Research. 3: 44-46.

Javidniaa M, Nasiri S, Far JK. 2012. Identifying factors affecting acceptance of new technology in the industry using hybrid model of UTAUT and FUZZY DEMATEL. Management Science Letters 2: 2383-2392.

Kurz JM. 2012. Enterprise 2.0: An extended technology acceptance model. The Sciences and Engineering Collection. 1283387486.

Mandal D, McQueen RJ. 2012. Extending UTAUT to explainsocialmediaadoptionby microbusinesses. International Journal of Managing Information Technology 4(4): 1-11.
Marques BP, Villate JE, Carvalho CV. 2011. Applying the UTAUT model in Engineering Higher Education: Teacher's Technology Adoption. Conferência Ibérica de Sistemas e Tecnologias de Informação. Portugal. CISTI:550-554.

NasirM. 2013. Evaluasipenerimaan teknologi informasi mahasiswa di Palembang menggunakan model UTAUT. Prosiding Seminar Nasional Aplikasi Teknologi Informasi. Yogyakarta: H.C.36-C.

O'Brien, Marakas. 2010. Introduction to Information System. United State of America: McGraw-Hill International.

Orji RO. 2010. Impact of gender and nationality on acceptance of a digital library: an empirical validation of nationality based UTAUT using SEM.Journal of Emerging Trends in Computing and Information Sciences 1(2): 68-79.

Oye ND, Iahad AN, Rahim NA. 2012. Acceptance and usage of ICT by university academicians using UTAUT model: a case study of university of Port Harcourt Nigeria. Journal of Emerging Trends in Computing and Information Sciences 3(1): 81-89.

Oye ND, Noorminshah A, Rahim NA. 2011. Examining the effect of technology acceptance model on ICT usage in Nigerian tertiary institutions. Journal of Emerging Trends in Computing and Information Sciences 2(10): 533-545.

Raman A. 2011. University management information system (UMIS) acceptance among university student: applying the extended technology acceptance model (ETAM). Journal of Studies in Education 1(1): 15.

Raman A, Don Y, Khalid R, Rizuan M. 2014. Usage of learning management system (moodle) among postgraduate students: UTAUT model. Asian Social Science 10 (14): 186-192.

Razavi SH, Attarnezhad O. 2013. Management of organizational innovation. International Journal of Business and Social Science 4 (1): 226-232.

Renny, Guritno S, Siringoringo H. 2013. Perceived usefulness, ease of use, and attitude towards online shopping usefulness towards online airlines ticket purchase. Procedia Social and Behavioral Sciences 81: 212-216.

Sedana IGN, Wijaya SW. 2010. UTAUT model for understanding learning management system. Internetworking Indonesia Journal 2(2):27-32.

Sutianto SD. 2015. Ini 20 BUMN laba terbesar, Bank XYZ geser posisi Pertamina. http://finance.detik. com. [26 Mei 2015]. 
Tane TP. 2014. Pengaruh adopsi teknologi informasi terhadap perilaku PNS melalui pendekatan UTAUT (studi: Kabupaten Maluku Barat Daya). [tesis]. Salatiga: Universitas Kristen Salatiga.

Teo T, Ömer FU, Bahçekapili E.2011.Efficiency of the technology acceptance model to explain preservice teachers' intention to use technology. Campus Wide Information Systems 28(2): 93101.
Venkatesh V, Morris MG, Davis GB, Davis FD.2003. User acceptance of information technology: Toward a unified view. MIS Quarterly 27(3):425478.

Wijanto SH. 2015.Metode penelitian menggunakan Structural Equation Modeling dengan LISREL 9. Jakarta: Lembaga Penerbit FE Universitas Indonesia. 